\title{
Relationship between the inflammatory infiltrate in bronchial biopsy specimens and clinical severity of asthma in patients treated with inhaled steroids
}

Jacob K Sont, J Han J M van Krieken, Christine E Evertse, Ria Hooijer, Luuk N A Willems, Peter J Sterk

\begin{abstract}
Background - Current guidelines on the management of asthma advocate the use of anti-inflammatory treatment in all but mild disease. They define disease control in terms of clinical criteria such as lung function and symptoms. However, the relationship between the clinical control of the disease and inflammation of the airways is not clear. A cross sectional study was therefore undertaken to investigate the relationship between airways inflammation and measures of clinical control and bronchial hyperresponsiveness in asthmatic patients treated with inhaled steroids.
\end{abstract}

Methods - Twenty six atopic adults (19-45 years) with mild to moderate asthma (baseline forced expiratory volume in one second $\left(F E V_{1}\right) \geq 50 \%$ predicted, concentration of histamine causing a $20 \%$ fall

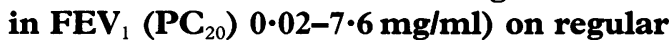
treatment with inhaled steroids entered the study. Diary card recordings during the two weeks before a methacholine challenge test and bronchoscopic examination were used to determine peak flow variability, symptom scores, and use of $\beta_{2}$ agonists. Biopsy specimens were taken by fibreoptic bronchoscopy from the carina of the right lower and middle lobes, and from the main carina. Immunohistochemical staining was performed on cryostat sections with monoclonal antibodies against: eosinophil cationic protein $\left(\mathbf{E G}_{1}, \mathbf{E G}_{2}\right)$, mast cell tryptase (AA1), CD45, CD22, CD3, CD4, CD8, CD25, and CD45RO. The number of positively stained cells in the lamina propria was counted twice by using an interactive display system.

Results - There were no differences in cell numbers between the three sites from which biopsy specimens were taken. The $\mathbf{P C}_{20}$ for methacholine was inversely related to the average number of total leucocytes, $\mathbf{E G}_{1}+$, and $\mathbf{E G}_{2}+$ cells, mast cells, CD8 +, and CD45RO + cells in the lamina propria. These relationships were similar for each of the biopsy sites. Symptom scores, $\beta_{2}$ agonist usage, $F E V_{1}$, and peak flow variability were not related to any of the cell counts.
Conclusions - Infiltration of inflammatory cells in the lamina propria of the airways seems to persist in asthmatic outpatients despite regular treatment with inhaled steroids. The number of infiltrating leucocytes such as mast cells, (activated) eosinophils, CD8 +, and CD45RO + cells in bronchial biopsy specimens from these patients appears to be reflected by airway hyperresponsiveness to methacholine, but not by symptoms or lung function. These findings may have implications for the adjustment of anti-inflammatory treatment of patients with asthma.

(Thorax 1996;51:496-502)

Keywords: atopic asthma, bronchial hyperresponsiveness, inflammatory infiltrate.

Asthma is a chronic inflammatory disorder of the airways with a characteristic infiltrate of mast cells, lymphocytes, and eosinophils in the bronchial epithelium and lamina propria. ${ }^{12}$ The symptoms of wheezing, chest tightness, difficult breathing, and coughing develop after exposure to bronchoconstrictor stimuli and are associated with variable airways obstruction ${ }^{3}$ which can be provoked in the laboratory, thereby demonstrating airway hyperresponsiveness. ${ }^{3}$ The disease state can therefore be assessed at different levels: the severity of symptoms, the level of obstruction and degree of airway hyperresponsiveness, and the extent of airway disease.

To date there is no "gold standard" parameter that ultimately reflects asthma severity towards which therapeutic interventions should be aimed. ${ }^{45}$ The present international consensus on the diagnosis and treatment of asthma is based on the working hypothesis that it is desirable to reverse or prevent airways inflammation..$^{2-4}$ However, at present the treatment level is solely guided by clinical indices such as symptoms and lung function ${ }^{34}$ and the current therapeutic approach is based on the assumption that there is a relationship between the clinical indices of asthma severity and airways inflammation.

When using the scoring system of Aas to assess symptoms over a one year period, it has been shown that the severity of the symptoms is related to the number and activity of eosinophils in the airways epithelium and in the bronchoalveolar lavage (BAL) fluid of patients \\ Pulmonology \\ C E Evertse \\ Hospital, \\ NL-2300 RC Leiden \\ Novern 1995
}


with atopic asthma. ${ }^{6-8}$ The forced expiratory volume in one second $\left(\mathrm{FEV}_{1}\right)$, expressed as a percentage of the predicted value, ${ }^{9-10}$ and airway hyperresponsiveness to inhaled methacholine $^{9-12}$ are positively related to the number and activity of eosinophils and activated CD4+ $\mathrm{T}$ cells in BAL fluid from subjects with atopic asthma. Furthermore, the provocative concentration of methacholine causing a $20 \%$ fall in $\mathrm{FEV}_{1}\left(\mathrm{PC}_{20}\right)$ has also been shown to be related to the number of activated eosinophils in bronchial biopsy specimens. ${ }^{71314}$ Hence, there is evidence that some of the clinical indices of asthma are associated with airways inflammation, at least in patients not on treatment with anti-inflammatory medications.

In order to adjust treatment in patients using anti-inflammatory drugs, the international guidelines rely on the following clinical characteristics: symptom severity, $\beta_{2}$ agonist usage, peak flow variability, and spirometric parameters. ${ }^{3415}$ To date it has not been systematically investigated which of these indices is most closely related to the level of airways inflammation in asthmatics using inhaled corticosteroids. In addition, it is still unclear whether measures of airways responsiveness can provide complementary information to symptoms and lung function on the disease state of the airways in these patients.

In the present study we have investigated whether clinical asthma severity, expressed according to present guidelines, is related to inflammatory activity in the airways of patients already using regular inhaled steroids. If so, such a relationship justifies the usage of clinical indices to adjust anti-inflammatory therapy. To that end we have assessed the relationship of symptom scores, $\beta_{2}$ agonist usage, peak flow variability, $\mathrm{FEV}_{1}$, and airways responsiveness to methacholine with mast cell number and number and activity of eosinophils and (sub) populations of lymphocytes in bronchial biopsy specimens from patients with atopic asthma who were on regular treatment with inhaled corticosteroids.

\section{Methods}

SUBJECTS

Twenty six non-smoking atopic adults (17 men, six ex-smokers) of mean age 29 years (range 19-45) with a wide range in asthma severity were asked to participate in the study (table 1) at the outpatient clinic of the University Hospital Leiden. All patients had a history of episodic chest tightness and wheezing in the previous year and were on regular treatment with inhaled corticosteroids for a mean (SD) of 21 (26) months. Atopy was indicated by a positive skin prick test ( $>3 \mathrm{~mm}$ weal) to one or more common airborne allergen extracts (Soluprick, ALK, Denmark). Pre-bronchodilator $\mathrm{FEV}_{1}$ was more than $50 \%$ of predicted ${ }^{16}$ and $>1.5 \mathrm{l}$, whilst post-bronchodilator $\mathrm{FEV}_{1}$ was within the normal range ( $>80 \%$ predicted). The $\mathrm{PC}_{20}$ for histamine at the start of the study was $0.02-7.3 \mathrm{mg} / \mathrm{ml}$ (geometric mean $0.42 \mathrm{mg}$ / $\mathrm{ml})$. Symptoms were additionally controlled by on demand usage of short acting $\beta_{2}$ agonists that were withheld for at least eight hours before each challenge test. All subjects gave their informed consent and the study was approved by the local ethical committee.

\section{STUDY DESIGN}

The study was of a cross sectional design. At entry to the study the subjects were equipped with diary cards and a mini-Wright peak flow meter and were asked to record symptoms, peak flow rates (PEF), and bronchodilator usage on the diary cards during the two weeks before the methacholine challenge test. Fibreoptic bronchoscopy was carried out 3-6 days later.

\section{DIARY CARDS}

The symptom score parameter was calculated from the diary card scores for night time asthma, morning tightness of the chest, daytime asthma, and daytime cough ${ }^{17}$ Each item could range from 0 to 4 on each day. The highest score for each day among these four items was then added up over a period of 14 days.

Bronchodilator usage was recorded as the total number of puffs of salbutamol or ipratropium bromide during 14 days registered on the diary cards and was expressed per week. ${ }^{15}$ PEF values were obtained from twice daily measurements, on waking and before bedtime, and from additional measurements when a bronchodilator had been used. Diurnal variability in PEF was expressed as the mean value of 14 days calculated from the highest minus the lowest daily value, divided by the highest. ${ }^{315}$

\section{INHALATION CHALLENGE TEST}

Methacholine inhalation challenge tests were performed according to a standardised tidal breathing method. ${ }^{18}$ The level of baseline lung function was determined as the mean of three reproducible values (within $5 \%$ ) of the $\mathrm{FEV}_{1}$ and was expressed as a percentage of the predicted value (FEV $\%$ pred). Doubling concentrations of methacholine in normal saline $(0.03-256 \mathrm{mg} / \mathrm{ml}$; Janssen Pharmaceutica, Beerse, Belgium) were aerosolised at room temperature by a DeVilbiss 646 nebuliser (output $130 \mathrm{mg} / \mathrm{min}$; DeVilbiss Co, Somerset, Pennsylvania, USA) operated by oxygen and connected to the central chamber of an inspiratory and expiratory valve box with an expiratory aerosol filter (Pall Ultipor BB50T). The aerosols were inhaled by tidal breathing for two minutes at five minute intervals through the mouth with the nose clipped. The response was measured as $\mathrm{FEV}_{1}$ recorded by a dry rolling seal spirometer (Morgan Spiroflow, Rainham, UK) 90 seconds after each dose. Bronchodilators were administered after completion of the test.

The response of $\mathrm{FEV}_{1}$ was expressed as the percentage fall from mean baseline value and was plotted against the log concentration of methacholine. The dose-response curves were characterised by their position, which was expressed as $\mathrm{PC}_{20}{ }^{18}$ 
Table 1 Patient characteristics, clinical indices of asthma severity and airways hyperresponsiveness to methacholine

\begin{tabular}{|c|c|c|c|c|c|c|c|c|c|c|}
\hline \multirow[t]{2}{*}{ Patient } & \multirow{2}{*}{$\begin{array}{l}\text { Age } \\
\text { (years) }\end{array}$} & \multirow[t]{2}{*}{ Sex } & \multicolumn{3}{|c|}{ Inhaled steroids } & \multirow{2}{*}{$\begin{array}{l}\text { Mean symptom } \\
\text { score }\end{array}$} & \multirow{2}{*}{$\begin{array}{l}\beta_{2} \text { agonist usage } \\
\text { (puffs/week) }\end{array}$} & \multirow{2}{*}{$\begin{array}{l}F E V_{1} \\
\text { (\% pred) }\end{array}$} & \multirow{2}{*}{$\begin{array}{l}\text { PEF } \\
\text { variability (\%) }\end{array}$} & \multirow{2}{*}{$\begin{array}{l}P C_{20}{ }^{*} \\
(\mathrm{mg} / \mathrm{ml})\end{array}$} \\
\hline & & & Dosage & /day) & Duration (months) & & & & & \\
\hline 1 & 21 & $\mathrm{M}$ & BDP & 400 & 12 & 2 & 9 & 51 & $18 \cdot 0$ & 0.45 \\
\hline 2 & 23 & $M$ & Bud & 1600 & 9 & 4 & 17 & 64 & $27 \cdot 1$ & 0.76 \\
\hline 3 & 26 & $\mathrm{~F}$ & $\mathrm{BDP}$ & 1000 & 11 & 2 & 5 & 66 & $15 \cdot 7$ & 0.27 \\
\hline 4 & 40 & $M$ & Bud & 400 & 21 & 3 & 18 & 68 & $12 \cdot 8$ & $5 \cdot 70$ \\
\hline 5 & 24 & $M$ & Bud & 400 & 1 & 9 & 0 & 68 & 21.5 & 0.02 \\
\hline 6 & 33 & $M$ & Bud & 800 & 2 & 3 & 14 & 81 & $26 \cdot 6$ & 0.68 \\
\hline 7 & 40 & $M$ & Bud & 1600 & 11 & 3 & 0 & 82 & $13 \cdot 3$ & 0.82 \\
\hline 8 & 20 & $M$ & Bud & 400 & 38 & 1 & 2 & 82 & $5 \cdot 7$ & $0 \cdot 11$ \\
\hline 9 & 21 & $M$ & BDP & 800 & 5 & 1 & 0 & 86 & $6 \cdot 3$ & 0.43 \\
\hline 10 & 22 & $\mathrm{M}$ & BDP & 2000 & 55 & 2 & 5 & 86 & $5 \cdot 1$ & $18 \cdot 17$ \\
\hline 11 & 21 & $\mathrm{M}$ & Bud & 800 & 19 & 1 & 0 & 88 & $3 \cdot 4$ & $3 \cdot 42$ \\
\hline 12 & 26 & $M$ & BDP & 400 & 50 & 0 & 0 & 91 & $2 \cdot 1$ & 2.01 \\
\hline 13 & 19 & $M$ & BDP & 1000 & 28 & 2 & 0 & 92 & $6 \cdot 3$ & 0.26 \\
\hline 14 & 29 & $M$ & Bud & 1600 & 7 & 5 & 14 & 93 & 4.9 & 0.63 \\
\hline 15 & 26 & $M$ & Bud & 400 & 13 & 9 & 51 & 96 & $9 \cdot 2$ & 0.28 \\
\hline 16 & 35 & $\mathrm{~F}$ & Bud & 400 & 37 & 3 & 3 & 96 & $9 \cdot 7$ & $0 \cdot 38$ \\
\hline 17 & 25 & $\mathrm{~F}$ & $\mathrm{BDP}$ & 800 & 1 & 2 & 3 & 96 & $2 \cdot 6$ & 3.86 \\
\hline 18 & 22 & $M$ & BDP & 200 & 1 & 2 & 14 & 97 & $7 \cdot 0$ & 0.46 \\
\hline 19 & 32 & $\mathrm{~F}$ & Bud & 400 & 20 & 0 & 1 & 99 & $7 \cdot 1$ & 0.22 \\
\hline 20 & 41 & $\mathrm{~F}$ & $\mathrm{BDP}$ & 400 & 8 & 1 & 0 & 99 & 6.0 & 1.63 \\
\hline 21 & 34 & $\mathrm{~F}$ & BDP & 800 & 43 & 5 & 28 & 101 & $10 \cdot 7$ & 0.32 \\
\hline 22 & 45 & $\mathrm{~F}$ & BDP & 1200 & 120 & 5 & 3 & 107 & $15 \cdot 8$ & 0.49 \\
\hline 23 & 32 & $\mathrm{~F}$ & Bud & 800 & 13 & 4 & 6 & 110 & $5 \cdot 1$ & $7 \cdot 61$ \\
\hline 24 & 26 & $\mathrm{~F}$ & Bud & 800 & 3 & 6 & 1 & 111 & $9 \cdot 1$ & 0.27 \\
\hline 25 & 36 & $M$ & BDP & 800 & 4 & 3 & 2 & 113 & $8 \cdot 8$ & $3 \cdot 16$ \\
\hline 26 & 26 & $M$ & BDP & 800 & 12 & 4 & 15 & 120 & $8 \cdot 4$ & 0.68 \\
\hline Mean (SD) & $29(7 \cdot 4)$ & & & & $21(26)$ & $3 \cdot 2(2 \cdot 3)$ & $8.0(11.5)$ & $90 \cdot 2(16.9)$ & $10 \cdot 3(6 \cdot 8)$ & $0.73(2.1)$ \\
\hline
\end{tabular}

$\mathrm{FEV}_{1}=$ forced expiratory volume in one second; $\mathrm{PEF}=$ peak expiratory flow; $\mathrm{PC}_{20}=$ concentration of methacholine provoking a $20 \%$ fall in $\mathrm{FEV}, \mathrm{BDP}=$ beclomethasone dipropionate; $\mathrm{Bud}=$ budesonide.

* Geometric mean (SD) in doubling dose.

BRONCHOSCOPIC EXAMINATION

Fibreoptic bronchoscopy was carried out by an experienced investigator (LNAW) using a standardised protocol according to recent recommendations. ${ }^{1920}$ In brief, the subjects were premedicated with atropine $0.5 \mathrm{mg}$ subcutaneously, codeine $20 \mathrm{mg}$ orally, and salbutamol $400 \mu \mathrm{g}$ by metered dose inhaler, and the nasal passages and the oropharyngeal space were sprayed with $10 \%$ lignocaine 30 minutes before the procedure. The lower airways were anaesthetised by nebulising a solution containing $2 \%$ lignocaine. Fibreoptic bronchoscopy was performed using a Pentax bronchoscope (outer diameter $6 \mathrm{~mm}$; Pentax Optical Co, Japan). Three bronchial biopsies were taken at (sub)segmental level from the right lower lobe, the middle lobe, and the main carina using a pair of cup forceps (Olympus FB-22C, Tokyo, Japan). Throughout the procedure $100 \%$ oxygen was delivered via a nasal cannula $(41 / \mathrm{min})$ and oxyhaemoglobin saturation was monitored continuously in all subjects using an oximeter (N-180, Nellcor Inc, Hayward, USA) with a finger probe.

PROCESSING OF ENDOBRONCHIAL BIOPSY SPECIMENS

Biopsy samples were immediately embedded in OCT medium (Miles Inc, Diagnostics Division, Elkhart, USA), and snap frozen in isopentane cooled by iced $\mathrm{CO}_{2}$. Samples were stored at $-70^{\circ} \mathrm{C}$ pending further processing. Six micrometer cryostat sections were air dried for one hour and fixed in a mixture of equal parts of acetone and methanol for two minutes. Immunohistochemical staining was performed using an indirect immunoperoxidase technique with monoclonal antibodies against: eosinophils staining for eosinophil cationic protein $\left(E G_{1}\right)$ or the secreted form of eosinophil cationic protein $\left(\mathrm{EG}_{2}\right)$ (both Pharmacia, Sweden), mast cell tryptase (AA1, donated by $\mathrm{Dr} R$ Djukanović, Southampton University General Hospital, Southampton, UK), total leucocytes (CD45), B cells (CD22), T lymphocytes (CD3), $\mathrm{T}$ helper cells (CD4), $\mathrm{T}$ suppressor cells (CD8), activated $\mathrm{T}$ cells (CD25) (all Becton Dickinson, Mountain View, California, USA), and $T$ cells CD45RO (UCHL1) (DAKO, Glostrup, Denmark).

QUANTITATIVE ANALYSIS OF BIOPSY SPECIMENS All biopsy specimens were coded and sections were examined twice at $200 \times$ magnification by one investigator (JKS) in a blind fashion by means of a video interactive display analysis system (VIDAS II, Kontron Electronik GmbH, Munich, Germany) at least one week apart. A total area of $0.123 \mathrm{~mm}^{2}$ was randomly chosen and presented on a video screen. The area of lamina propria was subsequently determined by delineating the widest possible $125 \mu \mathrm{m}$ deep zone beneath the epithelial basement membrane (at least $10000 \mu \mathrm{m}^{2}$ ), excluding damaged tissue and BALT. The number of positively stained cells was counted within this area and expressed as the number of cells $/ \mathrm{mm}^{2}$ calculated on pooled data of the two occasions.

\section{STATISTICAL ANALYSIS}

The differences in mean cell numbers between the three sites were tested by multiple analysis of variance (MANOVA). Spearman's rank correlation coefficients were used to assess the relationships of the following clinical indices of asthma severity as independent variables: symptom scores, $\beta_{2}$ agonist usage, $\mathrm{FEV}_{1} \%$ pred, peak flow variability, and the methacholine $\mathrm{PC}_{20}$ with the following dependent variables: average cell number $/ \mathrm{mm}^{2}$ for the three sites staining for $\mathrm{CD} 45, \mathrm{EG}_{1}, \mathrm{EG}_{2}, \mathrm{CD} 3, \mathrm{CD} 4$, CD8, CD25, CD22, CD45RO, and the CD4/ 
Table 2 Mean (SD) number of stained cells $/ \mathrm{mm}^{2}$ in the lamina propria at the (sub) segmental and central level in 26 atopic asthmatic subjects using inhaled corticosteroids

\begin{tabular}{lccc}
\hline Cells & $\begin{array}{l}\text { Right lower lobe } \\
(n=22)\end{array}$ & $\begin{array}{l}\text { Middle lobe } \\
(n=24)\end{array}$ & $\begin{array}{c}\text { Main carina } \\
(n=22)\end{array}$ \\
\hline CD45+ & $1354(705)$ & $1626(861)$ & $1471(686)$ \\
EG $_{1}+$ & $110(89)$ & $105(124)$ & $93(81)$ \\
EG $_{2}+$ & $118(123)$ & $86(105)$ & $81(116)$ \\
AA1+ & $175(105)$ & $157(86)$ & $182(111)$ \\
CD3+ & $1111(715)$ & $1446(878)$ & $1311(667)$ \\
CD4+ & $558(298)$ & $800(550)$ & $651(456)$ \\
CD8+ & $583(399)$ & $756(590)$ & $766(425)$ \\
CD22+ & $10(22)$ & $32(89)$ & $6(18)$ \\
CD45RO+ & $1514(1023)$ & $1792(851)$ & $1614(778)$ \\
CD4+/CD8+ & $1.09(0 \cdot 83)$ & $1.33(1.29)$ & $0.94(0.51)$ \\
\hline
\end{tabular}

Table 3 Relationships between cell counts $/ \mathrm{mm}^{2}$ in the lamina propria, averaged for the three sites, and clinical indices of asthma severity (Spearman's rank correlation coefficients)

\begin{tabular}{|c|c|c|c|c|c|}
\hline Cells & $\begin{array}{l}\text { Mean symptom } \\
\text { score }\end{array}$ & $\begin{array}{l}\beta_{2} \text { agonist } \\
\text { usage }\end{array}$ & $\begin{array}{l}F E V_{1} \\
\text { (\% pred) }\end{array}$ & $\begin{array}{l}P E F \\
\text { variability }\end{array}$ & $P C_{20}$ \\
\hline $\begin{array}{l}\mathrm{CD} 45+ \\
\mathrm{EG}_{1}+ \\
\mathrm{EG}_{2}+ \\
\mathrm{AA} 1+ \\
\mathrm{CD} 3+ \\
\mathrm{CD} 4+ \\
\mathrm{CD} 8+ \\
\mathrm{CD} 22+ \\
\mathrm{CD} 45 \mathrm{RO}+ \\
\mathrm{CD} 4+/ \mathrm{CD} 8+\end{array}$ & $\begin{array}{r}0.15 \\
0.17 \\
0.14 \\
0.15 \\
-0.03 \\
0.13 \\
-0.15 \\
0.06 \\
0.14 \\
0.28\end{array}$ & $\begin{array}{r}-0.14 \\
0.03 \\
0.01 \\
0.12 \\
-0.30 \\
0.06 \\
0.03 \\
-0.01 \\
-0.26 \\
0.12\end{array}$ & $\begin{array}{c}-0.10 \\
-0.21 \\
-0.23 \\
0.09 \\
0.01 \\
-0.01 \\
-0.34^{*} \\
0.02 \\
0.18 \\
0.13\end{array}$ & $\begin{array}{l}0 \cdot 29 \\
0.06 \\
0 \cdot 09 \\
0 \cdot 38^{*} \\
0 \cdot 04 \\
0 \cdot 15 \\
0 \cdot 25 \\
0 \cdot 13 \\
0 \cdot 11 \\
0.02\end{array}$ & $\begin{array}{l}-0.43^{* *} \\
-0.56^{* * *} \\
-0.58^{* * *} \\
-0.41^{* *} \\
-0.33^{*} \\
-0.28 \\
-0.47^{* *} \\
-0.28 \\
-0.43^{* *} \\
0.03\end{array}$ \\
\hline
\end{tabular}

$\mathrm{FEV}_{1}=$ forced expiratory volume in one second; $\mathrm{PEF}=$ peak expiratory flow; $\mathrm{PC}_{20}=\ln \left(\mathrm{PC}_{20}\right)$ to

methacholine.

CD8 ratio. MANOVA was used on the rank numbers to assess whether a significant relationship between the average number of a particular cell and clinical index was different among the three biopsy sites. The interaction term of the biopsy site and the clinical index was tested against the between subjects error term. $^{21}$ Results were considered significant when the chance of a type I error was $<5 \%$ $(p<0 \cdot 05)$. All analyses were performed using the SPSS-PC +.

\section{Results}

Results of the diary card recordings and lung function measurements are presented in table 1 . The average symptom score was $3 \cdot 2$, ranging from 0 to $9(16=$ maximum possible) and the average $\beta_{2}$ agonist usage was 8.0 puffs/week (range 0-51). The mean $\mathrm{FEV}_{1}$ before the methacholine challenge was $90 \%$ of predicted (range 51-120\% predicted). The mean PEF variability was $10 \cdot 3 \%$ (range $2 \cdot 1-27 \cdot 1$ ) and the geometric mean methacholine $\mathrm{PC}_{20}$ was $0.73 \mathrm{mg} / \mathrm{ml}$ (range $0.02-18.2 \mathrm{mg} / \mathrm{ml}$ ).

The mean (SD) numbers of (sub) populations of leucocytes per area (cells $/ \mathrm{mm}^{2}$ ) in the lamina propria of biopsy specimens at the subsegmental level of the right lower lobe, the segmental level of the middle lobe, and the central level of the main carina are shown in table 2. No significant differences in cell numbers were seen between the three sites. CD25 + cells were only found in one subject and were therefore excluded from statistical analysis. The relationships between the clinical indices of asthma severity and the average cell counts at the three sites are shown in table 3. The methacholine $\mathrm{PC}_{20}$ was inversely related to the mean number of total leucocytes $\left(r_{\mathrm{s}}=\right.$ $-0.43, \mathrm{p}=0.05), \mathrm{EG}_{1}+\left(r_{\mathrm{s}}=-0.56, \mathrm{p}<0.005\right)$ and $\mathrm{EG}_{2}+$ cells $\left(r_{\mathrm{s}}=-0.58, \mathrm{p}<0.005\right)$, mast cells $\left(r_{\mathrm{s}}=-0.41, \mathrm{p}=0.05\right), \mathrm{CD} 8+\left(r_{\mathrm{s}}=\right.$ $-0.47, \mathrm{p}<0.05)$, and CD45RO + cells $\left(r_{\mathrm{s}}=\right.$ $-0.43, \mathrm{p}<0.05$ ) (figs 1 and 2 ). There was a trend towards a negative relationship between the methacholine $\mathrm{PC}_{20}$ and CD3 + cells $\left(r_{\mathrm{s}}=\right.$ -0.33 , fig 2 ). There were no significant differ-
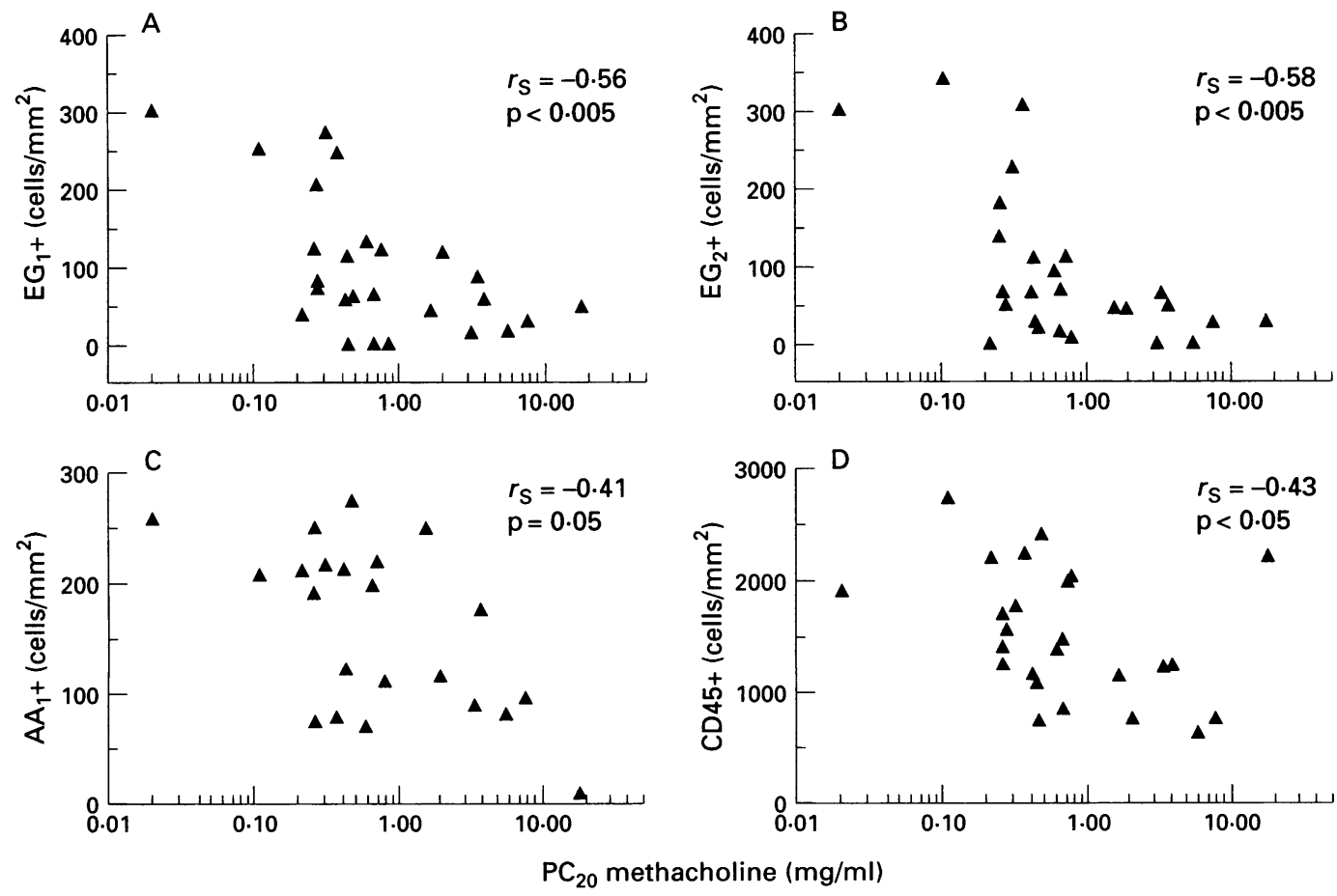

Figure 1 Relationship between airways responsiveness to methacholine and the number of $(A)$ eosinophils $\left(E G_{1}+\right)$, (B) activated eosinophils $\left(E G_{2}+\right),(C)$ mast cells $\left(A A_{1}+\right)$, and $(D)$ total leucocytes in the bronchial lamina propria averaged for three sites. Spearman's rank correlation coefficients are indicated. 

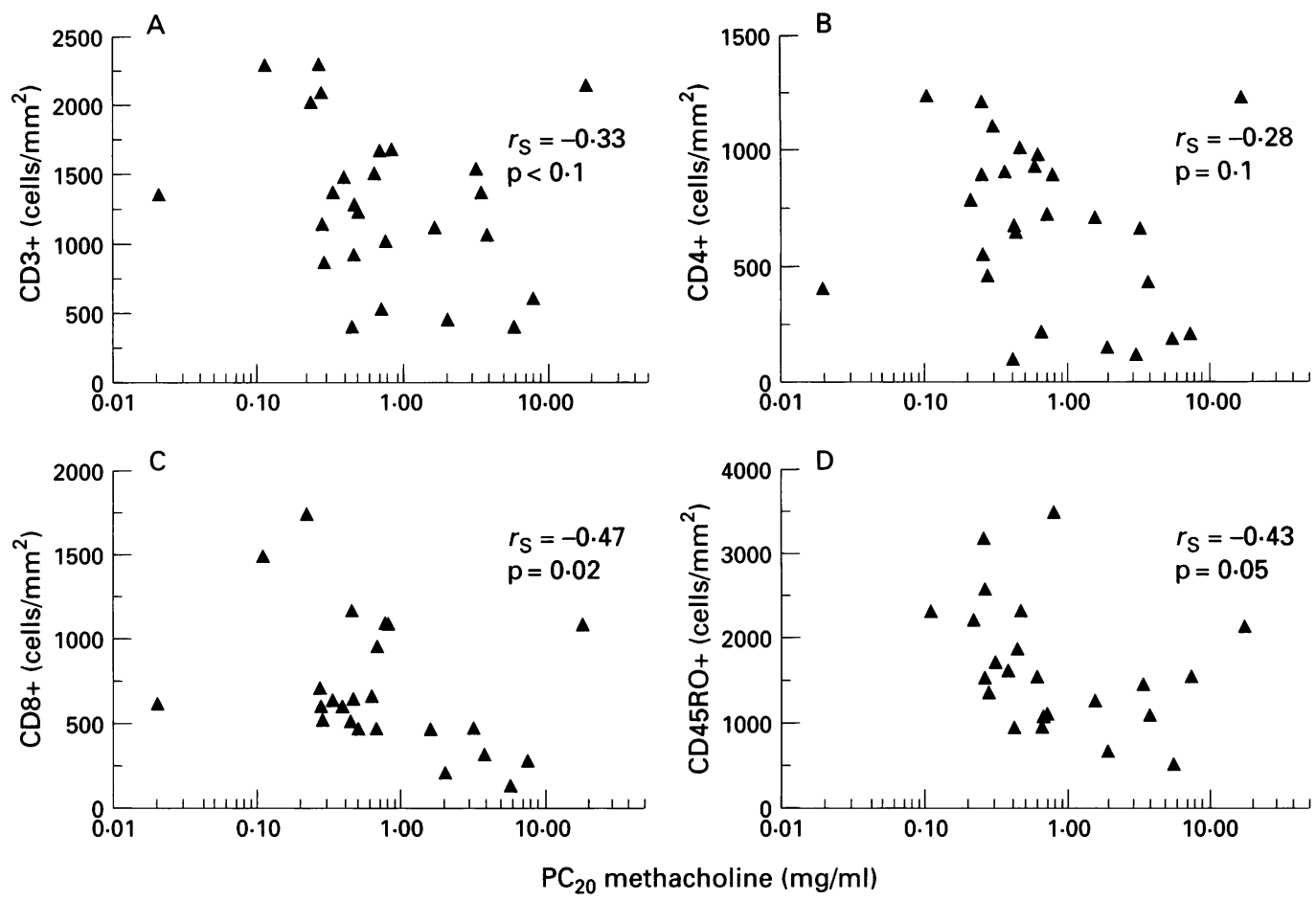

Figure 2 Relationship between airways responsiveness to methacholine and the number of $(A) C D 3+,(B) C D 4+$, (C) $C D 8+$, and (D) CD45RO+ in the bronchial lamina propria averaged for three sites. Spearman's rank correlation coefficients are indicated.

ences in the relationships between methacholine $\mathrm{PC}_{20}$ and the cell counts among the three biopsy sites.

Symptom scores, $\beta_{2}$ agonist usage, $\mathrm{FEV}_{1}$, and peak flow variability were not significantly related to any of the cells (table 3 ). However, there was a trend towards a negative relationship between $\mathrm{FEV}_{1} \%$ pred and $\mathrm{CD} 8+$ cells $(r=-0 \cdot 34)$ and between peak flow variability and the number of mast cells $(r=0 \cdot 38)$.

\section{Discussion}

This study shows that infiltration of inflammatory cells in the lamina propria of the airways seems to persist despite regular treatment with inhaled steroids in asthmatic outpatients. In addition, it appears that, among the clinical indices of asthma severity, the degree of airway hyperresponsiveness to methacholine is most closely related to the number of leucocytes, (activated) eosinophils, mast cells, $\mathrm{CD} 8$ +, and CD45RO + lymphocytes in bronchial biopsy specimens from atopic asthmatic subjects who are receiving treatment with inhaled steroids. This inverse relationship is a consistent one and is observed at the (sub) segmental level in the right lower lobe, the middle lobe, and the main carina. It is remarkable that the most commonly used clinical indices such as symptom severity, $\beta_{2}$ agonist usage, peak flow variability, and $\mathrm{FEV}_{1}$ are not significantly correlated with inflammatory cell counts in the lamina propria of the airways. These findings may have implications for the adjustment of anti-inflammatory treatment in asthma.

There have been a number of conflicting reports on the relationship between mast cell or eosinophil number in bronchial biopsy specimens and the clinical indices in atopic asthma. It has been reported that symptom severity over a one year period is related to the number and activity of eosinophils in the airway epithelium and in the BAL fluid in patients not on treatment with anti-inflammatory medications..$^{6-814}$ However, in our group of atopic asthmatic subjects using inhaled corticosteroids we could not establish a positive relationship between symptom scores and (activated) eosinophils. Our results confirm and extend those of Djukanović et $a l^{13}$ who could not demonstrate a correlation between symptom scores, $\beta_{2}$ agonist consumption, or peak flow variability and submucosal AA1 + mast cells or $\mathrm{EG}_{2}+$ eosinophils in subjects with asthma who were not treated with inhaled steroids. Our findings therefore further confirm that the currently recommended clinical indices of asthma severity do not reflect the extent of airways inflammation in this disease.

In contrast to symptoms and lung function, the degree of airways hyperresponsiveness appeared to be associated with the histopathology in our patients. Again, this has been a matter of controversy. An inverse relationship between the $\mathrm{PC}_{20}$ for methacholine and the number of activated eosinophils and mast cells in bronchial biopsy specimens has been reported previously in asthmatic patients without steroid treatment. $^{71422}$ However, other investigators were unable to confirm this. ${ }^{1323}$ This failure might have been due to a small sample size, or to a relatively narrow range in airways hyperresponsiveness compared with our study. The relatively weak relationship between $\mathrm{PC}_{20}$ and CD45RO + cells in our study confirms previous findings in a group of atopic asthmatic 
subjects who were not using inhaled corticosteroids. ${ }^{22}$ Thus, a relationship between airways hyperresponsiveness and histopathology may only be revealed by using a sufficiently large group of atopic asthmatics characterised by a wide range of airways hyperresponsiveness as in the present study.

The absence of a relationship between clinical indices of asthma severity and histopathology of the airways does not seem to be caused by patient selection, study design, statistical power, or the processing and analysis of bronchial biopsy specimens for the following reasons. Firstly, in order to ensure that time related variability in the measurements did not obscure potential associations, the bronchoscopy was carried out within six days of the $\mathrm{FEV}_{1}$ and $\mathrm{PC}_{20}$ measurements and last diary card registrations. Secondly, the patients in this study were carefully selected to be nonsmokers, having atopic asthma of mild to moderate severity with a wide range in $\mathrm{FEV}_{1}$ between $51 \%$ and $120 \%$ of the predicted value. Thirdly, with the present number of subjects a correlation coefficient of $\geq 0.40$ or $\leq-0.40$ yields a $\mathrm{p}$ value $<0.05$. Therefore, it seems unlikely that the absence of a significant correlation of modest strength can be explained by a problem with the power of the study. It can be argued that the use of inhaled steroids by these patients might have masked a potential relationship between clinical indices and cell counts. ${ }^{24}$ Due to the method of patient selection we cannot exclude such a possibility, because this study was designed to assess which parameter among the clinical indices best reflects the degree of airways inflammation in patients already using anti-inflammatory treatment.

The range and mean numbers of infiltrating inflammatory cells in the bronchial biopsy specimens in our study were slightly higher than those in other studies of asthmatic patients. ${ }^{232526}$ In those studies $\leq 1 \mu \mathrm{m}$ sections of specimens embedded in plastics were used, whereas our cell numbers were similar to those reported by Trigg et al who used $5 \mu \mathrm{m}$ cryostat sections. $^{24}$ The present histopathological methods are further validated by the highly consistent findings between the three sites in the tracheobronchial tree. We therefore believe that our results are unlikely to be explained by methodological errors.

How can the present results be interpreted? The association between eosinophils and mast cells in the lamina propria and methacholine responsiveness fits in with their role in the development of airways hyperresponsiveness. ${ }^{27}$ This includes secretion of a variety of inflammatory mediators capable of inducing epithelial desquamation, plasma extravasation, and hypersecretion, thereby increasing the thickness of the airway wall. ${ }^{128}$ The complexity of the pathophysiology of asthma is well illustrated by our present findings. In four subjects who reported symptoms we were unable to detect an infiltrate of eosinophils in the lamina propria. In contrast, some other subjects had clear evidence of airway inflammation in spite of the absence of symptoms and with lung function parameters within the normal range.
The latter finding extends observations in acute severe asthma indicative of a dissociation between clinical recovery and bronchial hyperresponsiveness $^{29}$ and is in keeping with a persistent increase in airways responsiveness in subjects who are clinically considered to be in remission of asthma. ${ }^{3031}$ Our findings seem to implicate that the presence of an inflammatory infiltrate does not in itself lead to symptoms of asthma or airways obstruction, but might point to long term disease activity.

According to the current international recommendations for the treatment of asthma ${ }^{3432}$ the level of anti-inflammatory treatment is chosen to minimise symptoms, optimise lung function, and to prevent exacerbations. The dosage of regular treatment should be kept to the minimum level that fulfils these objectives. The question is whether this approach leads to the optimal long term outcome of asthma. A number of studies have shown that treatment with inhaled steroids up to four months is very effective, particularly in reducing the number of mast cells and eosinophils in the airway wall which is often parallelled with improvements in symptoms, lung function, and airways hyperresponsiveness to methacholine. ${ }^{23243334}$ Longer term studies on the effect of inhaled steroids on the histopathology of the airways have not yet been reported. However, the observation that airways hyperresponsiveness continues to improve even after six months of treatment, when no further increase in $\mathrm{FEV}_{1}$ occurs, ${ }^{35-37}$ suggests that it may take relatively longer to resolve the airway histopathology.

It can be argued that maintenance of an inflammatory state of the airways may result in anatomical changes and functional disorders. ${ }^{1538}$ This might be reflected by abnormal $\mathrm{PC}_{20}$ levels since two recent population based prospective studies have shown that airways hyperresponsiveness is a significant predictor of subsequent accelerated decline in pulmonary function. ${ }^{3940}$ We therefore postulate that, in addition to the current guidelines, the treatment of asthma should also be directed towards reducing airways hyperresponsiveness. This might benefit the long term goal of asthma management as formulated in the international guidelines - that is, the prevention of the development of irreversible airways obstruction. ${ }^{153641}$ Clearly, such a treatment regimen needs to be tested in long term prospective studies.

The authors thank Dr R Djukanovic and Dr A F Walls for providing the AA1 monoclonal antibody specific for mast cell providing the AA1 monoclonal antibody specific for mast cell tryptase, and Henk Leenders of the Department of Cell Biology
for his help with the video interactive display analysis system. for his help with the video interactive display analysis system.
This study was supported by grant 92.45 of The Netherlands This study was supporte
Asthma Foundation.

1 Djukanović R, Roche WR, Wilson JW, Beasley CRW, Twentyman OP, Howarth PH, et al. State of the art. Mucosal inflammation in asthma. Am Rev Respir Dis 1990 142:434-57.

2 Corrigan CJ. Immunological aspects of asthma. Implication for future treatment. Clin Immunother 1994;1:31-42.

3 National Heart, Lung, and Blood Institute. National Institutes of Health Bethesda, Maryland. International conRespir f 1992;5:601-41.

4 British Thoracic Society. Guidelines on the management of asthma. Thorax 1993;48:S1-24.

5 Cockcroft DW. Therapy for airway inflammation in asthma. f Allergy Clin Immunol 1991;87:914-9. 
6 Bousquet J, Chanez P, Lacoste JY, Barnéon G, Ghavanian $\mathrm{N}$, Enander I, et al. Eosinophilic inflammation in asthma. N Engl f Med 1990;323:1033-9.

7 Bentley AM, Menz G, Storz Chr, Robinson DS, Bradley $\mathrm{B}$, Jeffery $\mathrm{PK}$, et al. Identification of T-lymphocytes, macrophages, and activated eosinophils in the bronchial mucosa in intrinsic asthma. Relationship to symptoms and bronchial responsiveness. Am Rev Respir Dis 1992; 146:500-6.

8 Robinson DS, Bentley AM, Hartnell A, Kay AB, Durham SR. Activated memory $T$ helper cells in bronchoalveola lavage fluid from patients with atopic asthma: relation to asthma symptoms, lung function, and responsiveness. Thorax 1993;48:26-32.

9 Kirby JG, Hargreave FE, Gleich GJ, O’Byrne PM. Bronchoalveolar cell profiles of asthmatic and nonasthmatic subjects. Am Rev Respir Dis 1987;136:379-83.

10 Walker C, Kaegi MK, Braun P, Blaser K. Activated T cells and eosinophilia in bronchoalveolar lavages from subjects with asthma correlated with disease severity. F Allergy Clin Immunol 1991;88:935-42.

11 Wardlaw AJ, Dunnette S, Gleich GJ, Collins JV, Kay AB. Eosinophils and mast cells in bronchoalveolar lavage in subjects with mild asthma. Relationship to bronchial hyperreactivity. Am Rev Respir Dis 1988;137:62-9.

12 Park CS, Lee SM, Uh ST, Kim HT, Chung YT, Kim YH, et al. Soluble interleukin-2 receptor and cellular profiles in bronchoalveolar lavage fluid from patients with bronchia asthma. $\mathcal{F}$ Allergy Clin Immunol 1993;93:623-33.

13 Djukanovic R, Wilson JW, Britten KM, Wilson SJ, Walls $\mathrm{AF}$, Roche WR, et al. Quantitation of mast cells and eosinophils in the bronchial mucosa of symptomatic atopic eosinophils in the bronchial mucosa of symptomatic atopic asthmatics and healthy control subjects using imm
histochemistry. Am Rev Respir Dis 1990;142:863-71.

14 Bradley BL, Azzawi M, Jacobson M, Assoufi B, Collins JV Irani AMA, et al. Eosinophils, T-lymphocytes, mast cell, neutrophils, and macrophages in bronchial biopsy specimens from atopic subjects with asthma: comparison with biopsy specimens from atopic asthmatic subjects withou asthma and normal control subjects and relationship to bronchial hyperresponsiveness. F Allergy Clin Immunol 1991;88:661-74.

15 Woolcock AJ. Assessment of bronchial responsiveness as a guide to prognosis and therapy in asthma. Med Clin North Am 1990;74:753-65.

16 Quanjer PhH, Tammeling GJ, Cotes JE, Pedersen OF, Peslin $\mathrm{R}$, Yernault JC. Lung volumes and forced ventilatory flows. Eur Respir f 1993;6(Suppl 16):5-40.

17 Harper GD, Neill P, Vathenen AS, Cookson JB, Ebden P. A comparison of inhaled beclomethasone dipropionate and nedocromil sodium as additional therapy in asthma. Respir Med 1990;84:463-9.

18 Sterk PJ, Fabbri LM, Quanjer PhH, Cockcroft DW, O’Byrne $\mathrm{PM}$, Anderson SD, et al. Airway responsiveness. Standardized challenge testing with pharmacological, physical and sensitizing stimuli in adults. Eur Respir f 1993;6(Supp 16):53-83.

19 Djukanović R, Wilson JW, Lai CKW, Holgate ST, Howarth $\mathrm{PH}$. The safety aspects of fiberoptic bronchoscopy, bronchoalveolar lavage, and endobronchial biopsy in asthma. Am Rev Respir Dis 1991;143:772-7.

20 Workshop summary and guidelines. Investigative use of bronchoscopy, lavage and bronchial biopsies in asthma and other airways diseases. Eur Respir f 1992;5:115-21.

21 Kleinbaum DG, Kupper LL, Muller KE. Applied regression analysis and other multivariable methods. 2nd edn. Boston: PWS-KENT Publishing Company, 1988.

22 Ackerman V, Marini M, Vittori E, Bellini A, Vassali G, Mattoli S. Detection of cytokines and their cell sources in bronchial biopsy specimens from asthmatic patients: relationship to atopic status, symptoms, and level of airway hyperresponsiveness. Chest 1994;105:687-96.

, Walls $\mathrm{AF}$, Roche WR, et al. Effect of an inhaled corticosteroid on airway inflammation and symptoms in asthma. $A m$ Rev Respir Dis 1992;145:669-74.

24 Trigg CJ, Manolitsas ND, Wang JH, Calderon MA, McAulay A, Jordan SE, et al. Placebo-controlled immunopathologic study of four months of inhaled corticosteroids in asthma. Am ₹ Respir Crit Care Med 1994;150:17-22.

25 Laitinen LA, Laitinen A, Haahtela T. Airway mucosal in flammation even in patients with newly diagnosed asthma. Am Rev Respir Dis 1993;147:697-704

26 Djukanović R, Lai CKW, Wilson JW, Britten KM, Wilson SJ, Roche WR, et al. Bronchial mucosal manifestations of atopy: a comparison of markers of inflammation between atopic asthmatics, atopic nonasthmatics and healthy controls. Eur Respir f 1992;5:538-44.

27 Sterk PJ, Bel EH. Bronchial hyperresponsiveness: The need for a distinction between hypersensitivity and excessive for a distinction between hypersensitivity and

28 Frigas E, Motojima S, Gleich GJ. The eosinophilic injury to the mucosa of the airways in the pathogenesis of to the mucosa of the airways in the pathogen

29 Whyte MKB, Choudry NB, Ind PW. Bronchial hyperresponsiveness in patients recovering from acute severe asthma Respir Med 1993:87:29-35.

30 Boulet LP, Turcotte H, Brochu A. Persistence of airway obstruction and hyperresponsiveness in subjects with asthma remission. Chest 1994;105:1024-31.

31 van Essen-Zandvliet EE, Hughes MD, Waalkens HJ, Duiverman EJ, Kerrebijn KF, and the CNSLD study group Remission of childhood asthma after long-term treatment with an inhaled corticosteroid (budesonide): Can it be achieved? Eur Respir ₹ 1994;7:63-8.

32 Hargreave FE, Dolovich J, Newhouse MT, eds. Rostrum The assessment and treatment of asthma: a conference report. $\mathcal{F}$ Allergy Clin Immunol 1990;85:1098-111.

33 Laitinen LA, Laitinen A, Haahtela T. A comparative study of the effects of an inhaled corticosteroid, budesonide, and a $\beta_{2}$ agonist, terbutaline, on airway inflammation in newly diagnosed asthma: a double-blind randomized in nllo

34 Jeffery PK, Godfrey RW, Adelroth E, Nelson F, Rogers A Johansson SA. Effects of treatment on airway inJohansson SA. Effects of treatment on airway in-
flammation and thickening of basement membrane reticular collagen in asthma. A quantitative light and electron ticular collagen in asthma. A quantitative light and electron

microscopic study. Am Rev Respir Dis 1992;145:890-9.
35 Kerstiens HAM, Brand PLP, Hughes MD, Robinson NJ Postma DS, and the Dutch CNSLD Study Group. A comparison of bronchodilator therapy with or without inhaled corticosteroid therapy for obstructive airways disease. $N$ Engl f Med 1992;327:1413-9.

36 Woolcock AJ, Yan K, Salome CM. Effect of therapy on bronchial hyperresponsiveness in the long-term management of asthma. Clin Allergy 1988;18:165-76.

37 Waalkens JH, van Essen-Zandvliet EEM, Gerritsen J, Duiverman EJ, Kerrebijn KF, Knol K. The effect of an inhaled corticosteroid (budesonide) on exercise-induced asthma in children. Eur Respir $\mathcal{F}$ 1993;6:652-6.

38 Brown PJ, Greville HW, Finucane KE. Asthma and irreversible airflow obstruction. Thorax 1984;39:131-6.

39 Rijcken B, Schouten JP, Xu X, Rosner B, Weiss ST. Airway hyperresponsiveness to histamine associated with achyperresponsiveness to histamine associated with ac1995;151:1377-82.

40 O'Connor GT, Sparrow D, Weiss ST. A prospective longitudinal study of methacholine airway responsiveness as a predictor of pulmonary function decline: the Normative Aging Study. Am F Respir Crit Care Med 1995;152:87-92.

41 Pattemore PK, Holgate ST. Bronchial hyperresponsivenes and its relationship to asthma in childhood. Clin Exp Allergy 1993;23:886-900. 